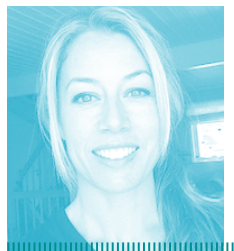

Gøril Salomonsen Klette, masterstudent, UNN og diabetessykepleier Bodø kommune og Diabetesforbundet

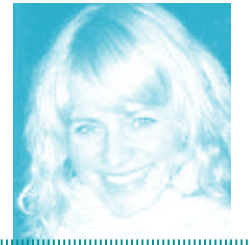

Anne Svelstad Evju, masterstudent, UNN, helsesøster og høgskolelærer ved $\mathrm{H} ø g$ skolen i Narvik

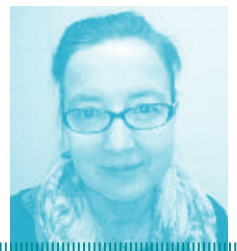

Anne Kasen, RN, PhD, førsteamanuensis, UNN og lektor ved Åbo Akademi, Finland

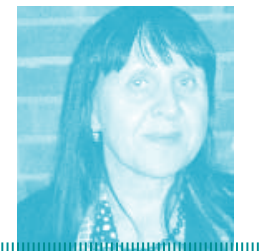

FAG

\section{Egenomsorg}

erese Bondas,

professor, HVD, HVL,

HVM, helsesøster, UNN

\title{
Helsefremmende pleie krever tid og kunnskap
}

\author{
Sykepleiere må ta mer ansvar for den helsefremmende delen av sykepleien.
}

0 ykepleierne ved nevrologisk avdeling har rapport. Pasienten det handler om er Geir på 47 år, som er innlagt etter et transitorisk iskemisk anfall (TIA). Han er overvektig og i løpet av sykehusoppholdet har man avdekket at han har en type 2-diabetes. Mye av grunnen til sykdommen skyldes Geirs usunne levevaner over flere år. Han er yrkessjåfør og lever det han kaller et ustrukturert liv. Han spiser få og store måltider og har ikke prioritert å være fysisk aktiv da han føler seg sliten. Vekten har økt gradvis de siste årene. Medisinsk behandling, pleie og omsorg er nødvendige faktorer for å ivareta Geirs helse. Men vil han få hjelp til å gjøre noe med sin hverdag, overvekt og diabetes? Hvem tar ansvar og hvordan organiseres dette?

\section{Økende problem}

Helseproblemer hos mennesker som følge av overvekt og inaktivitet er et økende fenomen (1). Det kan være nødvendig å endre levevaner for å unngå helsesvikt og sykdom. Sykepleiere møter disse pasientgruppene i ulike deler av helsetjenesten. Hensikten med artikkelen er å belyse helsefremmende sykepleie til mennesker som vil endre levevaner med Geirs tilfelle som eksempel. Sykepleiere har spesialisert kompetanse til å gi pleie og omsorg til

\section{Hovedbudskap}

Sykepleiere møter daglig pasienter som av helsemessige årsaker bør endre levevaner. Disse pasientene trenger kontinuitet og oppfølging på flere plan. Helsefremmende sykepleie bør vektlegges i hele behandlingskjeden og byr på faglige og organisatoriske utfordringer. Sykepleieren må skape tillit og ha mot til å ta opp pasientens levevaner.

\section{Nøkkelord}

Les mer og finn litteraturhenvisninger på våre nettsider. ) Mestring | Livskvalitet | Overvekt | Diabetes syke mennesker. Spørsmålet vi stiller i denne artikkelen er: Hvordan benyttes denne kompetansen for å ivareta den helsefremmende delen av sykepleien?

\section{Empowerment}

Ifølge yrkesetiske retningslinjer for sykepleiere er helsefremming en sentral sykepleiefunksjon (2). I sykepleie handler helsefremming om de tiltak som bidrar til mestring av egen helse slik at man unngår sykdom eller reduserer helseproblemer, men også om hjelp til å mestre langvarige helseproblemer og konsekvenser av disse på best mulig måte (1). Sentralt i helsefremming er empowerment-begrepet som WHO (3) definerer som: «En prosess som gjør folk i stand til å øke sin kontroll over egen helsetilstand og til å forbedre egen helse». Her gis en føring om at pasienten må trekkes inn i beslutningsprosessen rundt egen helse, og et syn på mennesket som aktør i sitt eget liv $(4,5)$. Veiledning er et middel i empowerment-prosessen, der hensikten er å styrke pasientens kompetanse og mestring. Empowerment betraktes som den nye formen for helsefremming, og innenfor sykepleien er det en bred oppfatning om at helsefremming bør utøves i tråd med empowerment (6).

\section{Metode}

Artikkelen baserer seg på vårt forskningsprosjekt hvor vi gjennomførte kvalitative intervjuer med sju sykepleiere som arbeidet på poliklinikk med overvekt, diabetes eller KOLS. Hensikten med forskningsprosjektet var å beskrive og fortolke sykepleieres erfaringer med helsefremmende sykepleie til pasienter som bør endre levevaner. Informantene arbeidet innenfor tre helseregioner, og alle var kvinner. De hadde jobbet som sykepleiere fra 10-25 år, og minst to år i poliklinikk.

\section{Nye behov}

Samhandlingsreformen krever at helse- og sosialpersonell har kunnskap om endring av helseatferd
(7). Det innledende eksempelet viser at sykepleiere møter pasienter med en akutt diagnose, hvor en underliggende faktor kan være helserisiko på grunn av overvekt, inaktivitet og et usunt kosthold. Blant våre informanter er det en oppfatning om at mange pasienter trenger støtte for å endre sine levevaner. Sykepleierne gir uttrykk for at yrkesrollen deres delvis har endret seg de siste årene; fra en rådgivende og undervisende funksjon til en mer veiledende. For å ivareta Geir og andre pasienter som har behov for å endre levevaner, må vi bort fra tanken om at «å gjøre for» er det beste. Helsepersonellets rolle som «ekspert» endres til brukermedvirkning der oppgaven blir å anerkjenne pasientens kompetanse på seg selv (5). Målet er å gi pasienten en aktiv rolle (8). I vårt eksempel med Geir kan sykepleieren gi generelle råd om kosthold, men hvis ikke rådene angår hans hverdag, vil de sjelden ha noen effekt. I stedet kan sykepleieren velge kartlegging ved å stille åpne spørsmål til Geir hvor hensikten er at han beskriver sitt kosthold. Hva er viktig for ham og hva er målet hans med å endre levevaner? Våre informanter opplever at informasjonen om livsstil pasientene får gjennom media og internett kan være en stor utfordring. De forteller at en stor del av veiledningen består av å hjelpe pasienten til å finne ut hva som er nyttig og dokumentert kunnskap.

\section{Helhetskunnskap}

Pasienter som skal endre levevaner har gjerne komplekse problemstillinger, og ofte helsemessige utfordringer i tillegg til at de trenger å endre levevaner. For eksempel kan vi tenke oss at Geir, for å fremme sin helse, vil ha behov for veiledning på flere områder, både om type 2-diabetes, medikamenter og levevaner. Vår studie viser at sykepleiere har kunnskap, både på det humanistiske, naturvitenskapelige og pedagogiske felt, som pasienten kan dra nytte av i endringsprosessen. Denne helhetskunnskapen oppleves også av enkelte som en hemsko 
ved ikke å være spesialister på de mest markerte felt innenfor helsefremmende utfordringer. Vår studie viser at det kan være utordrende for sykepleieren å finne sin rolle, når det er andre yrkesgrupper som er mer spesialiserte. Det er for eksempel vist at pasienter i en endringsprosess ønsker praktiske råd på feltene fysisk aktivitet og kosthold (9). Mange mener fysioterapeuten ivaretar den fysiske aktiviteten og at pasienten må henvises til en klinisk ernæringsfysiolog for kostveiledning. Likevel trykker våre informanter at de som yrkesgruppe har en bredde i kunnskapen sin som gjør at de kan ivareta en stor del av pasientens behov. En person med diabetes, kan få veiledning både om kosthold, aktivitet, blodsukker og medikamentbruk. Sykepleierne opplever at denne helhetskunnskapen de har vekker tillit hos pasientene. Annen forskning anbefaler multimodale intervensjoner, som omfatter medisinsk behandling og helsefremmende strategier. Her framkommer det også at sykepleiere og annet helsepersonell er godt posisjonert for å øke helsefremmende faktorer med pasienter og pårørende (10). De sykepleierne vi intervjuet framstiller et tverrfaglig samarbeid som viktig for pasientene og for de involverte yrkesgruppene. Sykepleierne må vite hva som hører til eget ansvarsområde og når pasienten må henvises videre. De understreker at samarbeidet ikke må være en «sovepute» for sykepleieren. I dette ligger at sykepleierne har tilstrekkelig kunnskap til å formidle råd for et sunt hverdagskosthold og motivere til økt aktivitet $\mathrm{i}$ hverdagen, og må ikke nødvendigvis henvise pasienter som Geir videre. Helsepersonelloven (11) viser til at dersom kunnskapene ikke strekker til, har hver enkelt et ansvar for å oppdatere seg.

\section{Behandlingskjeden}

Geir blir utskrevet fra sykehuset, og den medisinske behandlingen blir fulgt opp av fastlegen.

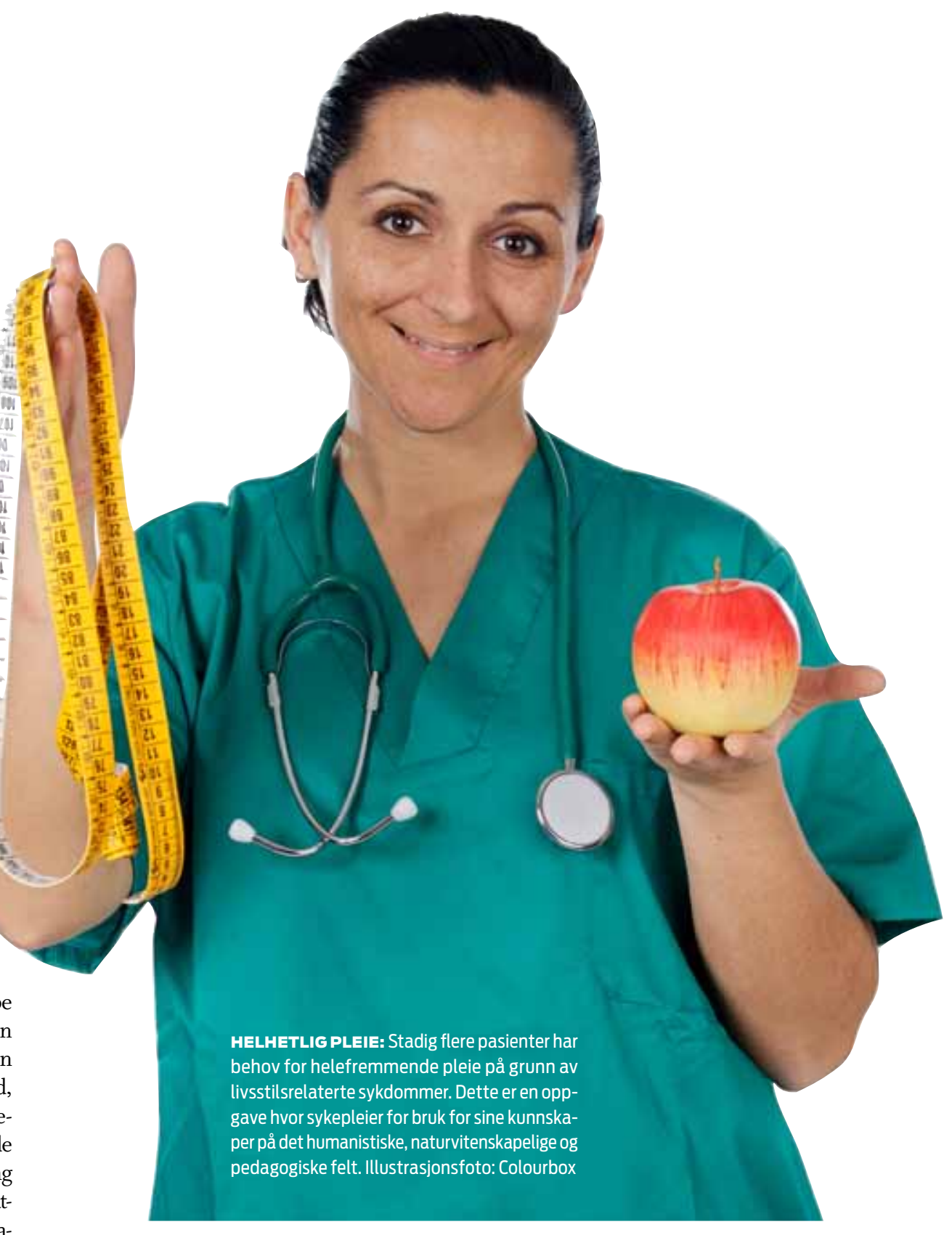

I kommunen arbeider det en diabetessykepleier som gir Geir veiledning om hvordan han kan håndtere sin type 2-diabetes. I tillegg blir han henvist til en frisklivssentral i kommunen hvor han får oppfølging med fast trening hver uke, «Bra mat»-kurs og helsesamtaler.

Sykepleiere arbeider innenfor mange ulike ledd i helsekjeden. Organiseringen må ligge til rette for at sykepleiere skal kunne gi pasientene et godt helsefremmende tilbud. Våre informanter framhevet organiseringen av behandlingskjeden til pasienten, og herunder samhandling mellom helseinstansene i spesialisthelsetjenesten og kommunen. En sier: «Jeg savner et mer helhetlig tilbud der vi kunne hatt kontinuitet.»

\section{Tilbud i kommunen}

Kommunene gir ulike tilbud til sine innbyggere. Hvis vi tar utgangspunkt i eksemplet med Geir, kan vi tenke oss at en sykepleier på sykehuset starter opp en miniintervensjon med veiledning og råd om kost og/eller fysisk aktivitet. På mange måter handler endringsveiledning om å hjelpe Geir ett skritt videre i endringsprosessen. Essensen her er at han også får et tilbud i sin hjemkommune. Mange kommuner har startet opp frisklivssentraler, som er kommunale kompetansesentre med tilbud til personer og grupper i befolkningen som har behov for hjelp til å endre helseatferd. Tilbudet inneholder blant annet endringsveiledning, tilrettelagt fysisk aktivitet og kostholdskurs. Dette er et prioritert tiltak i samhandlingsreformen (7) og et eksempel på at det nå opprettes arenaer innenfor kommunenes helse- og omsorgstjenestetilbud der helsepersonell kan arbeide helsefremmende og forebyggende (8). Flere kommuner har også opprettet stillinger for diabetessykepleiere, som fokuserer spesielt på forebygging og helsefremming av personer med type 2-diabetes. 

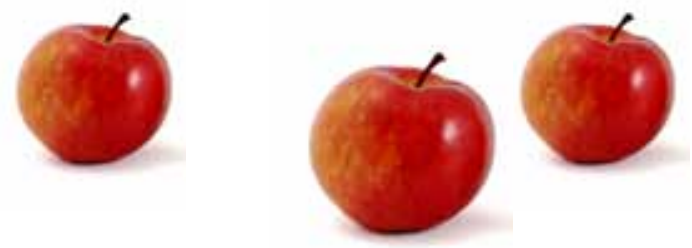

\section{Forskning}

Det er forsket på ulike modeller for å ivareta sykepleiefunksjonen til disse pasientgruppene i andre land. I Nederland har man introdusert en slags allmennpraktiserende sykepleier som blant annet måler blodtrykk, blodsukker og vekt. Sykepleieren veileder i forhold til levevaner og diabetes (12). I England og USA har dette vært en utbredt ordning. Studier viser til gode erfaringer med en slik sykepleierolle. En nederlandsk studie på allmennpraktiserende sykepleiere viser også at pasientene var tilfredse med hvordan sykepleierne koordinerte omsorgen. Sykepleierne tilbød gjerne lengre og hyppigere konsultasjoner og ga mer informasjon til pasientene enn legene hadde mulighet til å gjøre (13). sessen med å endre levevaner. Dette krever tid og kontinuitet i oppfølgingen.

\section{Tidkrevende}

Tid er et aktuelt tema for sykepleierne i vår undersøkelse. Noen oppgir at tiden de har per konsultasjon på poliklinikken er for knapp til å ta tak i pasientens levevaner. Spesielt når det meste av konsultasjonen går til undersøkelser og prøver. Enkelte opplever at det er vanskelig å ta opp slike temaer med pasienten når det ikke står på agendaen i utgangspunktet. Andre av våre informanter er fleksible og kan sette av tid til veiledning av levevaner, og sammen med pasienten bli enige om hvor ofte konsultasjoner er nødvendig. Flere framhever handlingsfrihet som en viktig faktor

\section{«Sykepleierne har tilstrekkelig kunnskap til å formidle råd for et sunt hverdagskosthold og motivere til økt aktivitet i hverdagen.»}

\begin{abstract}
Ulike modeller
Man kan tenke seg alternative løsninger i fremtiden, der sykepleiere med relevant kompetanse kan avlaste allmennlegen i oppfølgingen av disse pasientene. Skal det være hensiktsmessig å starte intervensjoner på endring av levevaner i spesialisthelsetjenesten, er det essensielt at dette følges opp av tilbud i pasientenes hjemkommuner. Et ønskelig mål er en helhetlig og sammenhengende behandlingskjede for pasienten, og en mulighet er at pasientene følges opp av en og samme sykepleier både i poliklinikk og i hjemkommunen. Et annet alternativ kan være et godt samarbeid og kompetanseutveksling mellom sykepleier på poliklinikk og ansvarlig sykepleier i primærhelsetjen.
\end{abstract}

\section{«Det private helserom»}

Levevaner kan ofte føles private, og våre informanter beskriver det å gå inn på andres levevaner og helse som å gå inn i «det private helserom». Det ligger en forventning i dagens samfunn om at generelle helseråd blir fulgt opp av den enkelte. Når det ikke skjer, kan pasienten oppleve det som en personlig svakhet og få skyldfølelse. Da kan det være vanskelig å åpne seg opp for andre, også for helsepersonell. I eksempelet om Geir kan en konsekvens av at sykepleieren bare forteller hva han ikke bør spise, være at han opplever motløshet i stedet for motivasjon til endring. Vi fant at sykepleierne tok utfordringen på alvor og brukte ressurser for å bygge opp tilliten underveis i pro- for å gi pasientene den individuelle oppfølgingen de trenger. Sykepleiere ansatt i poliklinikker som ikke er organisert slik at de er fleksible, opplever at de ikke strekker til når det gjelder veiledning på endring av levevaner. Dette støttes av tidligere forskning $(12,14,15)$. En undersøkelse gjort i Finland (15) viser at et stort antall leger og sykepleiere i kommunehelsetjenesten ser veiledning rettet mot livsstilsendring som en viktig oppgave, samtidig som arbeidshverdagen gjør det utfordrende å ta seg tid til å gå inn på pasientens levevaner.

\section{I praksis}

Lov om kommunale helse- og omsorgstjenester (16) krever at helsefremmende og forebyggende arbeid skal inngå i alle kommunale helse- og omsorgstjenester. Dette utfordrer sykepleiere til å ta ansvar for den helsefremmende delen av pleien. I vårt tilfelle med Geir kan det være en enkel løsning å overse hans behov for helsefremmende oppfølging $\mathrm{i}$ arbeidshverdagen. Selv om helsefremming og forebygging er lovbasert, så er det ikke noe som kan måles og avhenger dermed av rutiner på avdelingen og den enkelte sykepleiers engasjement. Hvis sykepleiere reelt skal kunne ta tak i problemstillinger som i Geirs tilfelle, må det gis opplæring, klar ansvarsfordeling og tid til gjennomføring. Helsefremming må prioriteres. I vår studie ser vi at sykepleiere har generelle kunnskaper om hvordan de skal fremme helse hos pasienten i tråd med empowerment-tenkningen, men tidligere forskning viser at sykepleiere generelt er usikre på hvordan de skal gå frem for å fremme helse i eget fag og trenger mer kompetanse på dette $(6,17)$. Mer vektlegging av helsefremmende pleie på bachelorutdanningen i sykepleie kan etter vårt skjønn være et hensiktsmessig tiltak. I den praktiske sykepleiehverdagen kan hjelpemidler med fokus på helsefremmende faktorer være til hjelp, som eget punkt i behandlingsplan eller -rapport, skjemaer for pasienters målsettinger og aktivitetsplaner. Det kan være nødvendig med en bevisstgjøring på hvordan sykepleiere møter pasienter som skal endre levevaner. Hvilke spørsmål som stilles og hvordan de blir stilt, vil ha betydning for pasientenes mulighet for refleksjon og motivasjon.

\section{Avslutning}

Sykepleiere møter pasienter på mange ulike arenaer i helsevesenet. For å kunne ivareta pasienter som Geir og andre i liknende situasjoner, må sykepleiere ta ansvar, oppdatere sine kunnskaper og følge opp den helsefremmende delen av sykepleien. For å praktisere helsefremmende sykepleie kreves det også en hensiktsmessig organisering og relevant opplæring, som ledere bør prioritere. Sykepleiere må synliggjøre dette behovet for sine ledere. Vi mener sykepleiere er betydningsfulle for å fremme helse både i det tverrfaglige samarbeidet og som en selvstendig gruppe. IIII

\section{REFERANSER}

1. Lerdal A, Fagermoen MS. Læring og mestring. Oslo: Gyldendal, 2011.

2. Norsk Sykepleieforbund ICN-Yrkesetiske retningslinjer for sykepleiere. Oslo: NSF, 2007. 3. WHO (1998): Health Promotion Glossary, Geneva. http://www.who.int/healthpromotion/about/HPR\%20Glossary\%201998.pdf (05.1.1.12).

4. Askheim OP, Starrin B. Empowerment. Oslo: Gyldendal, 2007

5. Tveiten S. Denvet best hvor skoen trykker-: omveiledningiempowermentprosessen. Bergen: Fagbokforlaget, 2007.

GammersvikA,Alvsvåg H. Forståelse av helsefremming isykepleie. Nordisk Tidsskrift for Helseforskning 2009;5:18-29.

7. St.meld.nr. 47. Samhandlingsreformen. Rett behandling - på rett sted - til rett tid. Oslo: Helse- og omsorgsdepartementet.http://www.regieringen.no/nb/dep/hod/ dok/regpubl/stmeld/2008-2009/stmeld-nr-47-2008-2009-.html?id=567201 (12.10.12)

8. Larsen T,Gammersvik $\AA$. Helsefremmende sykepleie. Bergen: Fagbokforlaget, 2012. 9. Oftedal BF. Motivation for self-management among adults with type 2 diabetes. Journal of Nursing and Healthcare of Chronic Illness. 2011; 25(4):735-744.

10. LawrenceM, Fraser H, Woods C, McCall J. Secondary prevention og stroke and transient ischaemic attack Nursing Standard 2011; 26:41-46.

11. Helsepersonelloven. Lovomhelsepersonell m.v. http://www.lovdata.no (01.1.1.12).

12. Jansink R, Braspenning J, Weijden T, Elwyn G, Grol R. Primary carenurses struggle with lifestyle counseling in diabetes care: a qualitative analysis. BMC Family Practice 2010;11. doi:10.1186/1471-2296-11-41.

13. Dierick-van Daele ATM, Derckx JFM, Spreeuwenberg EW, Vrijhoef H. Nurse practitioners substituting for general practitioners: randomized controlled trial. Journal of Advanced Nursing 2009; 65: 391-401

14. Frantsen K. Motivasjon for egenbehandling hos voksne med type 2 diabetes- En utfordring for sykepleiere. Masteroppgave. Stavanger: UiS, 2010.

15. Jallinoja P, Kuronen R, Nissinen A, Talja M, Uutela A, Patja K. The dilemma of patient responsibility for lifestyle change: perceptions among primary care physicians and nurses Scandinavian Journal of Primary Health Care 2007; 25(4): 244-249.

16. St.meld. nr. 16. Nasjonal helse og omsorgsplan (2011-2015) Oslo: Helse- og omsorgsdepartementet. http://www.regjeringen.no/nb/dep/hod/dok/regpubl/
sol.mol sorgsdepartementet.http://www.regjeringen.no/nb/dep/hod/dok/regg
stmeld/2010-2011/meld-st-16-20102011/2.html?id=639796 (27.09.11).

17. Berg GV. Å fremme den eldre sykehuspasientens helsei lys av et folkehelse- og et holistisk-eksistensielt sykepleieperspektiv. Doktorgradsavhandling. Göteborg: Nordiska Högskolan för folkhälsovetenskap, 2007.

Fagartikler kan sendes til torhild.apall@sykepleien.no 